\title{
Cemental tear: A case report with nonsurgical periodontal therapy
}

\section{Dilaceração cementária: Relato de caso clínico com terapia periodontal não cirúrgica}

\begin{abstract}
Purpose: To report a case of cemental tear, a rare periodontal condition characterized by total or partial separation of the dental cementum, mainly addressing issues related to its diagnosis and treatment.

Case description: A 50 years-old man sought dental assistance complaining of pain located in the mandibular left second premolar that showed a $4 \mathrm{~mm}$ probing depth with the presence of a foreign body in the distal gingival sulcus. Radiographic examination demonstrated a slight radiopaque fragment detached from the root. The fragment was removed without a periodontal flap. Histopathological examination was performed and evidenced the presence of a cementum fragment with cementum lamellae, cementocytes, and adhered periodontal ligament fibers, confirming the diagnosis of cemental tear.

Conclusion: After a follow-up of 2 years, the nonsurgical periodontal therapy showed satisfactory clinical and radiographic outcome. Therefore, this approach should be a suitable and predictable treatment modality for the cemental tear.
\end{abstract}

Key words: Dental cementum; periodontal diseases; dental scaling

\section{Resumo}

Objetivo: Relatar um caso de dilaceração cementária, uma condição periodontal rara caracterizada pela separação total ou parcial do cemento dental, abordando principalmente aspectos relativos ao seu diagnóstico e tratamento.

Descrição do caso: Um homem de 50 anos procurou assistência odontológica queixando-se de dor localizada no segundo molar inferior que apresentava profundidade de sondagem de $4 \mathrm{~mm}$ com presença de um corpo estranho no sulco gengival da face distal. $O$ exame radiográfico demonstrou um fragmento radiopaco destacado da raiz. $\bigcirc$ fragmento foi removido sem cirurgia periodontal. $\bigcirc$ exame histopatológico demonstrou tratar-se de um fragmento de cemento com presença de lamelas cementárias, cementócitos e fibras do ligamento periodontal, confirmando o diagnóstico de dilaceração cementária.

Conclusão: Após dois anos, o tratamento periodontal não cirúrgico demonstrou aspectos clínicos e radiográficos satisfatórios. Portanto, a terapia periodontal não cirúrgica pode ser uma modalidade de tratamento adequada e previsível para a dilaceração cementária.

Palavras chave: Cemento dentário; doença periodontal; raspagem dentária

\author{
Leonardo Silveira Damasceno a \\ Walderez Ornelas Dutra a \\ Eder Gonçalves Melgaço b \\ Paulo Eduardo Alencar de Souza \\ Elton Gonçalves Zenóbio c \\ Martinho Campolina Rebello Horta ${ }^{c}$
}

- Laboratory of Cell-Cell Interactions, Department of Morphology, Universidade Federal de Minas Gerais, Belo Horizonte, MG, Brazil

b Private Practice, Belo Horizonte, MG, Brazil c Department of Dentistry, Pontifícia Universidade Católica de Minas Gerais, Belo Horizonte, MG, Brazil
Correspondence:

Martinho Campolina Rebello Horta

Rua Dom José Gaspar 500, Prédio 46, Sala 111

Belo Horizonte, MG - Brazil

30535-610

E-mail: martinhohorta@pucminas.br

Received: September 30, 2011

Accepted: December 13, 2011

Conflict of Interests: The authors state that there are no financial and personal conflicts of interest that could have inappropriately influenced their work.

Copyright: (C) 2011 Damasceno et al.; licensee EDIPUCRS. This is an Open Access article distributed under the terms of the Creative Commons AttributionNoncommercial-No Derivative Works 3.0 Unported License. 


\section{Introduction}

Cementum is a dental hard tissue that acts functionally in the insertion apparatus embedding the collagen fibers of periodontal ligament to the root surface. Cementum is a nonuniform, mineralized connective tissue composed by $50 \%$ of inorganic matrix in the form of hydroxyapatite crystals. Organic matrix consists of type I collagen fibrils (approximately 90\%) and type III collagen fibrils (approximately 5\%). Dental cementum also contains noncollagenous proteins, glycolipids, glycoproteins and proteoglycans. As an avascular tissue it does not undergo continuous remodeling. The cementum-dentin junction is characterized by penetrating cytoplasmic processes of precementoblasts in the array of pre-dentin with subsequent deposition of collagen fibers, forming interdigitations (1).

Cemental tear has been described as an rare periodontal condition characterized by a total or partial separation of the cementum (2-6). This detachment mainly occurs in the cementum-dentin junction, and may also include dentin $(2,7)$. According to the current classification of periodontal diseases, cemental tears are categorized as localized toothrelated factors that modify or predispose to plaque-induced gingival diseases and periodontitis (8).

The cementum displacement can occur in the midcervical or in the apical root (4) and its diagnosis can be confirmed by clinical signs and symptoms, radiographic findings (2), and surgical inspection (5). Cemental tear is more often observed in men with a mean age of 63.1 years, involving single-rooted vital or nonvital teeth, especially the incisors and premolars (2-7).

Its etiology has been related to traumatic occlusion (3), dental trauma $(5,9)$, or a poor capacity of tissue repair due to age (4). The cementum fragments, exposed or not to the oral environment, can initiate a localized attachment loss and several treatment approaches have been suggested: scaling and root planning (10), open flap debridement (4), bone graft (11), regenerative tecidual guide (12), and extraction in cases of poor prognosis (7).

The present article aimed to report a case of cemental tear, mainly addressing issues related to its diagnosis and treatment.

\section{Description of the case}

A 50 years-old man sought dental assistance complaining of pain located in the mandibular left second premolar that had been used as the abutment of fixed partial denture for twelve years. The patient informed that the pain had occurred previously, leading to the decision of performing endodontic re-treatment. Nevertheless, the sensitivity persisted. Dental trauma was not reported and periapical radiography showed satisfactory endodontic treatment.

The clinical examination showed a good periodontal condition. No significant dental biofilm, calculus or bleeding on probing were observed. The probing depth measurements were less than $3 \mathrm{~mm}$ with no suppurative sites. Nevertheless, the distal surface of the mandibular left second premolar displayed signs of periodontal inflammation. Bleeding on probing as well as a coincident probing depth and periodontal attachment loss of $4 \mathrm{~mm}$ were detected in this area. Moreover, a foreign body was observed in this specific site. The radiographic examination showed a foreign body located partially inside the periodontal ligament (Fig. 1A). Clinical signs and symptoms and radiographic appearance suggested the diagnosis hypothesis of cemental tear.
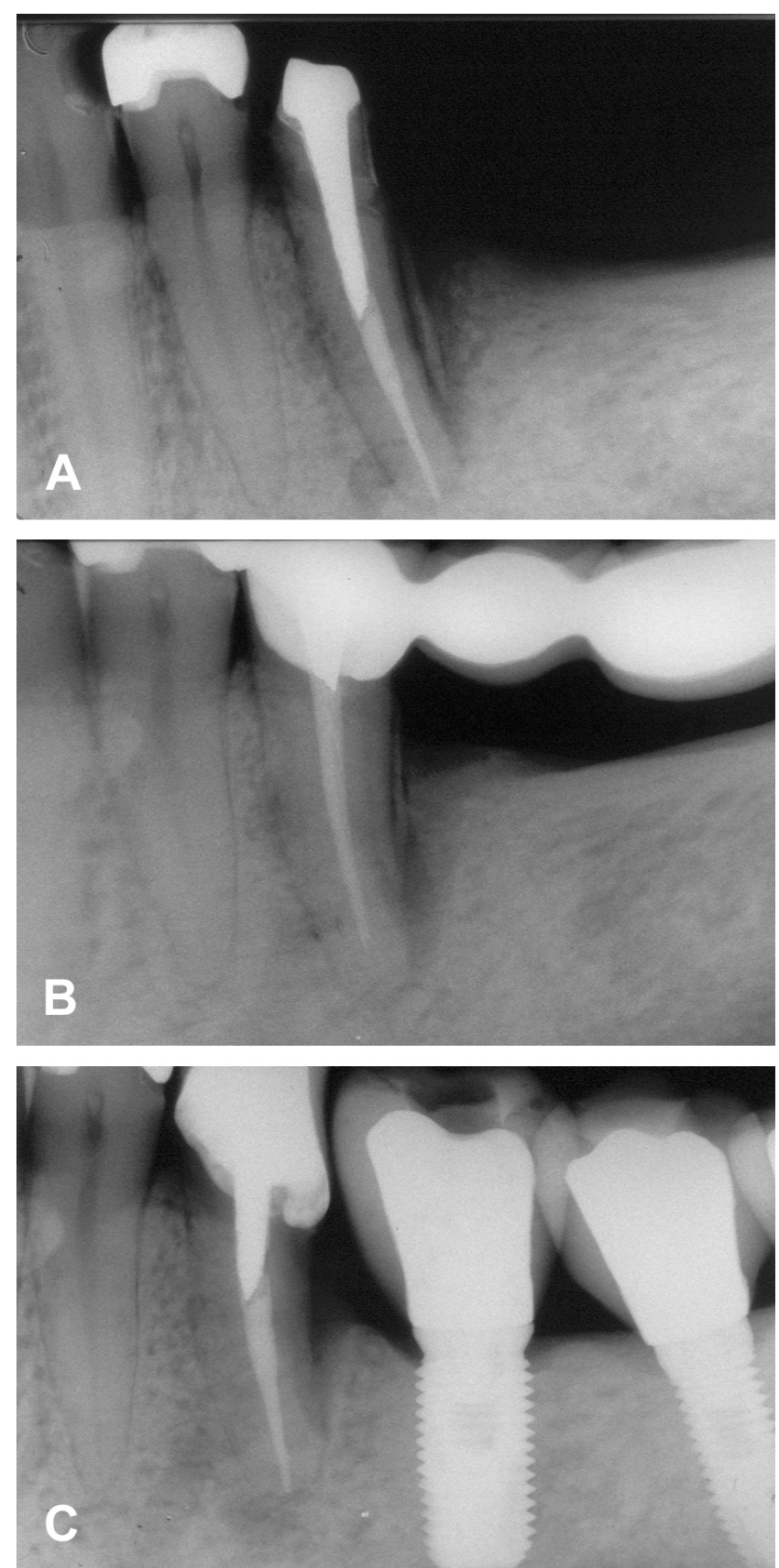

Fig. 1. Periapical radiographs showing: (A) radiopaque aspect of the distal fragment in the mandibular left second premolar, suggesting cemental tear; (B) one year before the fragment removal; and (C) satisfactory aspect on the alveolar bone twenty four months after removal of the cemental tear. 
Previous periapical radiographs allowed the detection of the beginning of the cementum detachment (Fig. 1B). Probably, during a period of approximately one year, the cemental tear come through the periodontal ligament to erupt in the oral cavity via the gingival sulcus.

The fragment was removed with the aid of tissue pliers, under local anesthesia, without opening flap, followed by scaling and root planing. The patient was instructed to keep a mechanical control of dental biofilm. The fragment
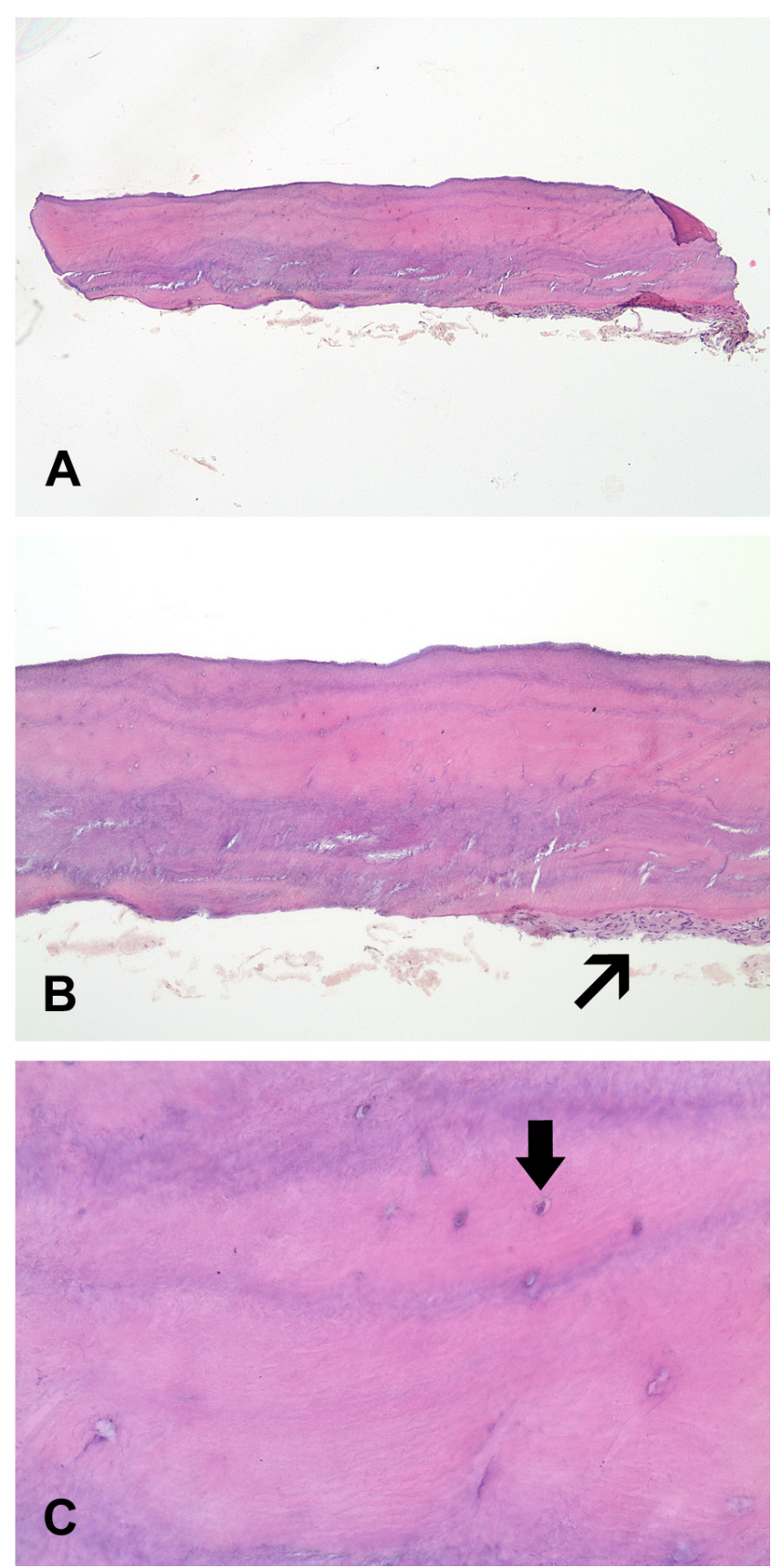

Fig. 2. Light microscopy showing the cementum fragment and confirming the diagnosis of cemental tear (A, HE-x40). Cementum lamellae can be observed as well as adhered periodontal ligament fibers (thin arrow) (B, HE-x100) and cementocytes (thick arrow) (C, HE-x400). was sent to the Oral Pathology Laboratory of Pontifícia Universidade Católica de Minas Gerais to routine evaluation. Histopathological examination evidenced the presence of a cementum fragment showing lamellae and cementocytes, as well as adhered periodontal ligament fibers, confirming the diagnosis of cemental tear (Fig. 2A, B, C).

After a follow-up of 2 years, the nonsurgical periodontal therapy showed satisfactory clinical and radiographic outcome (Fig 1C).

\section{Discussion}

Few cases of cemental tear have been reported (2-7,9-13), demonstrating that this is a rare condition. It affects some localized areas of specific teeth, mainly in single-rooted teeth incisors and premolars (2). The main clinical sign is the presence of localized periodontal pockets with exudates and localized pain (2-7,9-13).

Radiographic examination is almost always essential to the diagnosis (2). In the proximal surfaces, the displaced cementum appears radiographically as a radiopaque fragment inside the periodontal ligament (2-4). Nevertheless, in buccal or lingual surfaces, this image can be masked by the tooth root, complicating the diagnosis $(5,9)$. In these cases, computed tomography should be used to make a differential diagnosis among root fracture and cemental tears (9).

The case reported showed characteristic radiographic features. The presence of radiographic evidence of the cemental tear has been frequently observed by previous reports $(2,6,7)$. Nonetheless, some reported cases did not show radiographic evidences and the definitive diagnosis was established only after tooth extraction (9) or after periodontal flap surgery and inspection (5). These situations can result in a misdiagnosis of root fracture (6). Moreover, the unusual occurrence of the cemental tear leading to its misdiagnosis can result in unnecessary tooth extraction or endodontic treatment, as initially occurred in the case reported.

Although few cases have been described in the literature, cemental tears can be a more common finding (3). Since fragments of cementum can completely detach from the root, move along the periodontal ligament and erupt in the oral cavity, the symptoms should disappear and the condition may never be diagnosed. According to the literature, the separation occurs mainly in the cementum-dentin junction (2-4), even though it can also involve dentin $(2,7)$. The displacement probably occurs more frequently in cementumdentin junction due to the physical characteristics of this union (2).

While traumatic occlusion is described as the main cause of cemental tear $(2,3)$, age $(4)$ and dental trauma $(5,9)$ may also play a role in its development. In this case report, the probable cause was traumatic occlusion, since the patient's age was not advanced and the affected tooth had been used as the abutment of fixed partial denture for twelve years. In an in vitro trial, Nona et al. (14) showed that a cumulative effect of stress caused by repeated loading on premolars can develop breaks in the cemento-enamel junction, leading to 
a non-carious cervical lesion, as well as a breakdown along the root, facilitating the formation of cemental tears.

Due to the accumulation of dental biofilm and inflammation, cemental tears have been associated to localized bone loss (3). In the case reported, the attachment loss was relatively small (4 $\mathrm{mm})$, probably due to the removal of the cemental tear just after it became exposed.

The treatment of cemental tears involves scaling and root planing (10), open flap debridement (4), bone graft (11), regenerative tissue guide (12) or dental extraction (9). Nonsurgical treatment for periodontal diseases has been advocated as the first therapy of choice since scaling and root planning are effective in the resolution of periodontal diseases, reducing the depth of periodontal pockets of nonmolar teeth (15). In the context of the case reported, as part of the cementum fragment was exposed to the oral environment and the probing depth was $4 \mathrm{~mm}$, only nonsurgical treatment was performed. This approach demonstrated clinical and radiographic efficacy, twenty four months after the procedure. Conservative intervention should be considered in cases in which the cemental tear is exposed, since it causes less morbidity, as well as reduces the treatment time and cost.

In conclusion, the knowledge of the clinical and radiographic features of the cemental tear is important in dental practice and nonsurgical periodontal therapy should be a suitable and predictable treatment modality for this uncommon lesion.

\section{Acknowledgments}

The authors wish to thank the invaluable technical assistance provided by Mrs. Maria Reni Gonçalves Moitinha.

This study was partially supported by grants from Conselho Nacional de Desenvolvimento Científico e Tecnológico $(\mathrm{CNPq})$, Fundação de Amparo à Pesquisa do Estado de Minas Gerais (FAPEMIG), and Fundo de Incentivo à Pesquisa da PUC Minas (FIP-PUC Minas), Brazil.

\section{References}

2. Chou J, Rawal YB, O’Neil JR, Tatakis DN. Cementodentinal tear: a case report with 7-year follow-up. J Periodontol 2004;75:1708-13.

3. Leknes KN, Lie T, Selvig KA. Cemental tear: a risk factor in periodontal attachment loss. J Periodontol 1996;67:583-8.

4. Ishikawa I, Oda S, Hayashi J, Arakawa S. Cervical cemental tears in older patients with adult periodontitis. Case reports. J Periodontol 1996;67:15-20.

5. Camargo PM, Pirih FQ, Wolinsky LE, Lekovic V, Kamrath $H$, White SN. Clinical repair of an osseous defect associated with a cemental tear: a case report. Int J Periodontics Restorative Dent 2003;23:79-85.

6. Tulkki MJ, Baisden MK, McClanahan SB. Cemental tear: a case report of a rare root fracture. J Endod 2006;32:1005-7.

7. Tai TF, Chiang CP, Lin CP, Lin CC, Jeng JH. Persistent endodontic lesion due to complex cementodentinal tears in a maxillary central incisor - a case report. Oral Surg Oral Med Oral Pathol Oral Radiol Endod 2007; 103:e55-60.

8. Blieden TM. Tooth-related issues. Ann Periodontol 1999;4:91-7.

9. Stewart ML, McClanahan SB. Cemental tear: a case report. Int Endod J 2006;39:81-6.

10. Brunsvold MA, Lasho DJ. Cemental tears related to severe localized periodontal disease. Pract Periodontics Aesthet Dent 2000;12:536,539-540.

11. Harrel SK, Wright JM. Treatment of periodontal destruction associated with a cemental tear using minimally invasive surgery. J Periodontol 2000;71:1761-6.

12. Müller HP. Cemental tear treated with guided tissue regeneration: a case report 3 years after initial treatment. Quintessence Int 1999;30:111-5.

13. Marquam BJ. Atypical localized deep pocket due to a cemental tear: case report. J Contemp Dent Pract 2003;4:52-64.

14. Noma N, Kakigawa H, Kozono Y, Yokota M. Cementum crack formation by repeated loading in vitro. J Periodontol 2007;78:764-9.

15. Badersten A, Nilvéus R, Egelberg J. Effect of nonsurgical periodontal therapy. I. Moderately advanced periodontitis. J Clin Periodontol 1981;8:57-72. 